\section{Synthesis of Multicyclic $\beta$-Lactam Derivatives via Solid-Phase-Generated Ketenes}

\author{
Luciana Méndez and Ernesto G. Mata* \\ Instituto de Química Rosario (IQUIR). Facultad de \\ Ciencias Bioquímicas y Farmacéuticas, Universidad \\ Nacional de Rosario, CONICET, Suipacha 531, \\ S2002LRK Rosario, Argentina
}

\section{Received July 22, 2010}

$\beta$-Lactams are arguably one of the most important heterocyclic skeletons in organic chemistry. Because of their unique biological properties, $\beta$-lactam derivatives have been the object of intense investigation in synthetic and medicinal chemistry areas. Since the discovery of penicillin, a number of bicicylic $\beta$-lactams have found broad applicability in antibacterial therapy. Aside from penicillin analogues, many cephalosporins, carbapenems, oxapenams, etc., are also currently used as effective weapons in the fight against bacteria. ${ }^{1,2}$ More recently, the significance of $\beta$-lactams has reached new frontiers, mostly because of the discovery of derivatives that show biological activities such as inhibition of prostate specific antigen, ${ }^{3}$ thrombin, ${ }^{4}$ human cytomegalovirus protein, ${ }^{5}$ human leukocyte elastase, ${ }^{6}$ cholesterol absorption, ${ }^{7}$ cysteine protease, ${ }^{8}$ and human fatty acid amide hydrolase $;{ }^{9}$ as well as neuroprotective action. ${ }^{10}$

For more than a decade, the rapid emergence of bacterial resistance has caused a serious concern in the antiinfectious therapy, mostly due to bacterial mutation and gene exchange. ${ }^{11}$ Consequently, a number of novel strategies directed to the synthesis of new $\beta$-lactam antibiotics have been reported. ${ }^{12}$ Among them, preparation of multicyclic $\beta$-lactam compounds have emerged as an interesting alternative, leading to a new generation of antibiotics known as trinems (1), with good stability against $\beta$-lactamase and dehydropeptidase deactivation, ${ }^{13}$ and also to compounds with potent activity against class $\mathrm{A}$ and class $\mathrm{C} \beta$-lactamases (2) (Figure 1). ${ }^{14}$ Moreover, some multicyclic $\beta$-lactams (3) have found interest in the area of cholesterol absorption inhibition, ${ }^{15}$ while other related structures (4) have shown significant activity against different human cancer cell lines. ${ }^{16}$

In recent years, we have developed a series of solidsupported synthetic strategies for the generation of libraries of $\beta$-lactam compounds. ${ }^{17}$ We envisioned that the Staudinger reaction between imines and immobilized ketenes ${ }^{18}$ would be useful for achieving an efficient solid-phase synthesis of biologically promising multicyclic $\beta$-lactams.

To establish a solid-phase route to multicyclic carbacepham derivatives, the immobilized 4-hydroxyphenoxyacetic acid (5) was used as precursor for the in situ formation of the ketene $\mathbf{6}$ (Scheme 1). Resin-bound acid $\mathbf{5}$ was obtained in two steps from Wang resin. ${ }^{18}$ Thus, ketene $\mathbf{6}$ reacts with

* To whom correspondence should be addressed. E-mail: mata@ iquir-conicet.gov.ar. Fax: +54341 4370477. phenantridine (7) to yield the corresponding C-3-anchored tetracyclic $\beta$-lactam 9, which was corroborated by gel-phase ${ }^{13} \mathrm{C} \mathrm{NMR}^{19}$ where the spectrum showed the presence of the $\beta$-lactam fused to the 6-membered ring, especially from the peaks at 57 and 89 ppm, corresponding to C-6 and C-7, respectively. Final treatment of the resin 9 with 10\% trifluoroacetic acid in $\mathrm{CH}_{2} \mathrm{Cl}_{2}$ afforded the carbacepham analogue $\mathbf{1 0}$ in a $57 \%$ overall yield, after isolation by column chromatography (based on the initial loading level of the Wang resin). It is interesting to note that, under homogeneous phase reaction conditions, similar products were obtained in low yield and as a mixture of isomers. ${ }^{15}$

${ }^{1} \mathrm{H}$ NMR coupling constant between hydrogens at C-6 and $\mathrm{C}-7$ positions of the $\beta$-lactam ring denotes a 6,7-trans stereochemistry. This is clearly in agreement with a ketene-imine mechanism for the $\beta$-lactam formation (Scheme 2). Being 7 a cyclic imine, the orthogonal approach between the reactant species lead to the zwitterionic intermediate $\mathbf{1 1}$ which, by conrotatory electrocyclization, generates the 6,7-trans product $(\mathbf{9}) .^{20}$

This solid-phase strategy was used for the generation of a small array of 1,2-benzofused carbacepham employing a series of 3,4-dihydroisoquinoline derivatives as imine component (Scheme 3). ${ }^{21}$ Interestingly, when 3,4-dihydroisoquinoline (12a, $R=R^{\prime}=H$ ) was used as the cyclic imine, formation of the expected benzofused carbacepham 13a was clear by gel-phase ${ }^{13} \mathrm{C}$ NMR, however, separation from the solid support has proved to be unsuccessful, probably due to the lack of stability of the tricyclic $\beta$-lactam under the cleavage conditions.

Better results were obtained with other 3,4-dihydroisoquinolines. Thus, 6,7-dimethoxy-1-aryl-3,4-dihydroisoquinolines $(\mathbf{1 2 b}-\mathbf{e})$ were synthesized by a Bishler-Napieralski reaction, using phosphorus oxychloride as dehydrating agent. $^{22}$ To perform the solid-phase version of the Staudinger cyclization, the immobilized carboxylic acid 5 was treated successively with the 6,7-dimethoxy-1-aryl3,4-dihydroisoquinoline (12b-e) (5 equiv), triethylamine (6 equiv), and Mukaiyama's reagent (8) (3 equiv), followed by refluxing in chloroform for $2 \mathrm{~h}$, and the reaction was repeated to ensure complete formation of the product $(\mathbf{1 3 b}-\mathbf{e})($ Scheme 3$) .{ }^{23}$ Characterization of the resin-bound benzofused carbacephams $13 \mathbf{b}-\mathbf{e}$ were
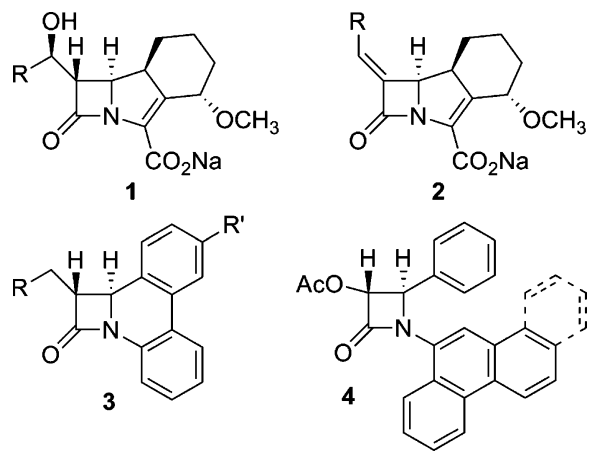

Figure 1 


\section{Scheme 1}
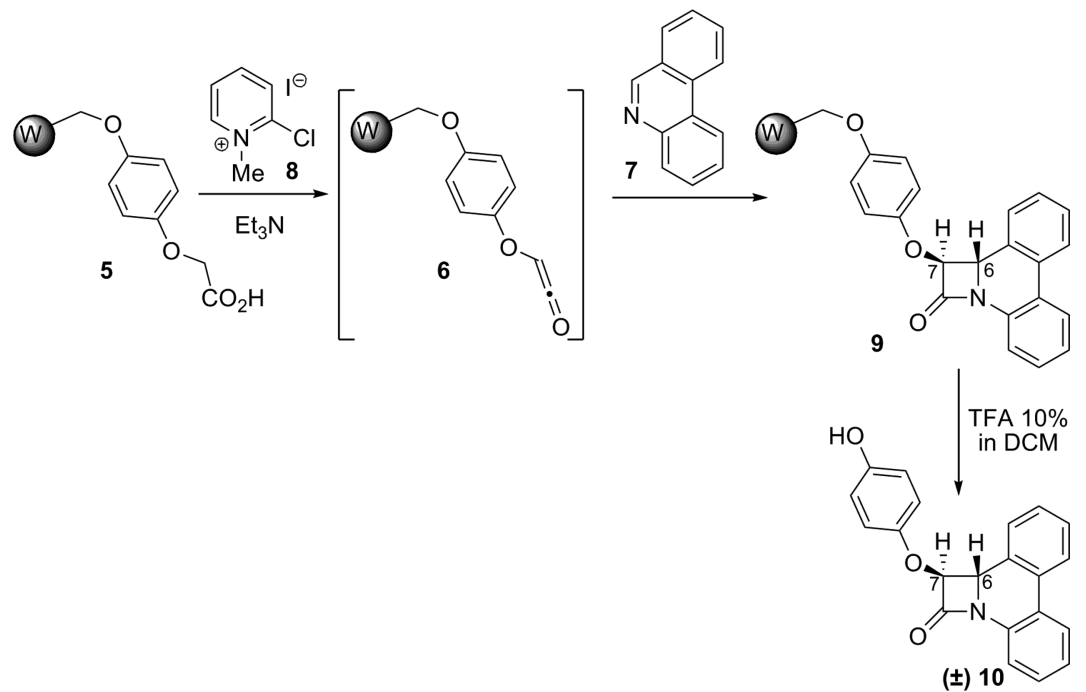

\section{Scheme 2}

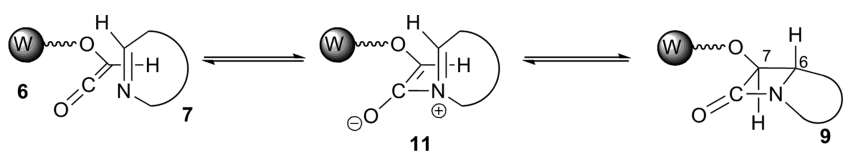

achieved by solid-phase FTIR $^{24}$ spectra that showed the $\beta$-lactam carbonyl absorption peak at $\sim 1772 \mathrm{~cm}^{-1}$, and the gel-phase ${ }^{13} \mathrm{C}$ NMR (Figure 2). The cleavage of the immobilized tricyclic $\beta$-lactams from the resin was carried out with $10 \%$ trifluoroacetic acid in $\mathrm{CH}_{2} \mathrm{Cl}_{2}$ for $1 \mathrm{~h}$ at room temperature. The corresponding benzofused carbacephams $\mathbf{1 4 b}-\mathbf{e}$ were obtained in very good overall yield, after isolation by column chromatography.

A nuclear Overhauser effect (NOE) experiment allowed us to corroborate the relative configuration of the substituents at C-6 and C-7 positions. ${ }^{1} \mathrm{H}$ NMR NOE experiments demonstrated that these substituents are in a cis relationship. As seen in Figure 3, the experiment was carried out on carbacepham 14d, and shows that irradiation at the singlet at $5.36 \mathrm{ppm}$, corresponding to $\mathrm{H}-7$, causes a clear enhancement of the signal at $6.74 \mathrm{ppm}$, assigned to the $\mathrm{H}-9$ of the fused aromatic ring. The presence of the aryl group bound to C-6 places both substituents at C-6 and
C-7 positions at the same face of the bicyclic azetidinonepiperidine system.

In conclusion, it is well-known the biological importance of bicyclic $\beta$-lactams, which include penicillins, cefalosporins, penems, carbapenems, carbacephems, oxacephems, and clavams, among other structures. Despite their undoubted significance, very few solid-phase methods have been reported in literature for the construction of multicyclic $\beta$-lactam systems; ${ }^{25}$ actually, most of the procedures are related to the preparation of monocyclic $\beta$-lactams (monobactams). ${ }^{26}$ Now, we are extending the scope of these methodologies by adding an efficient synthetic sequence for the solid-phase preparation of multicyclic $\beta$-lactam derivatives. Key step is the cycloaddition reaction between an immobilized ketene and different cyclic imines to afford the corresponding benzofused carbacepham derivatives in high yield for the overall synthetic sequence. Stereoselectivity at the stereogenic centers of the newly formed $\beta$-lactam ring is in agreement with a ketene-imine mechanism. We believe that the in situ generated immobilized ketenes ${ }^{18}$ have demonstrated their effectiveness for the application of the

\section{Scheme 3}

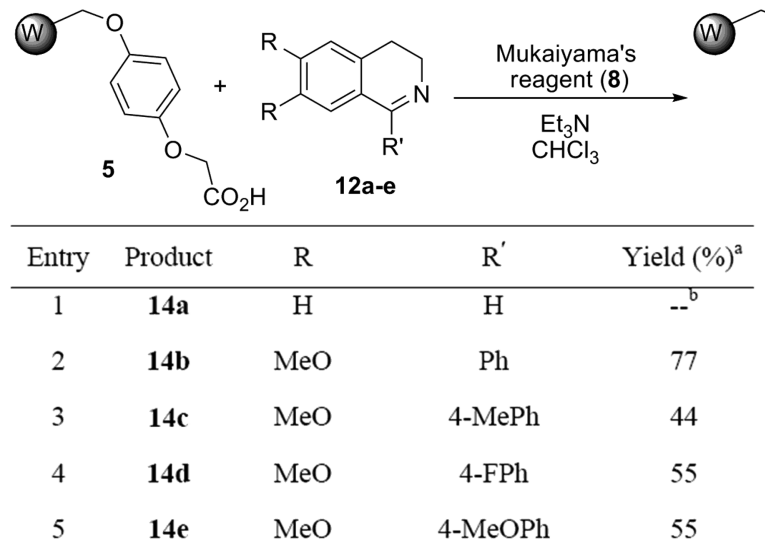

${ }^{a}$ Overall isolated yield after flash chromatography (based on the initial loading level of Wang resin). 'see text.

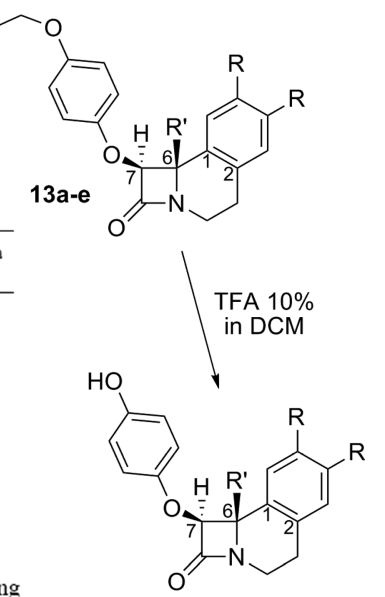

(士) 14a-e 


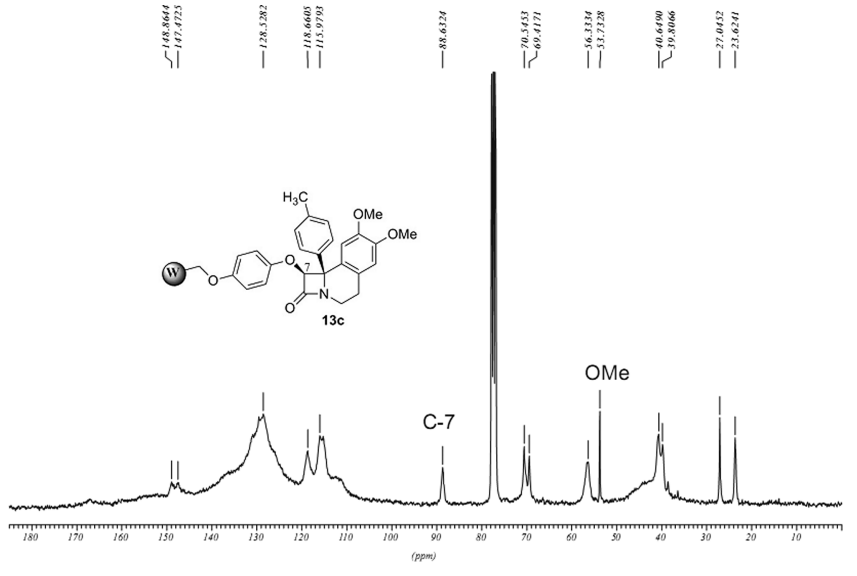

Figure 2

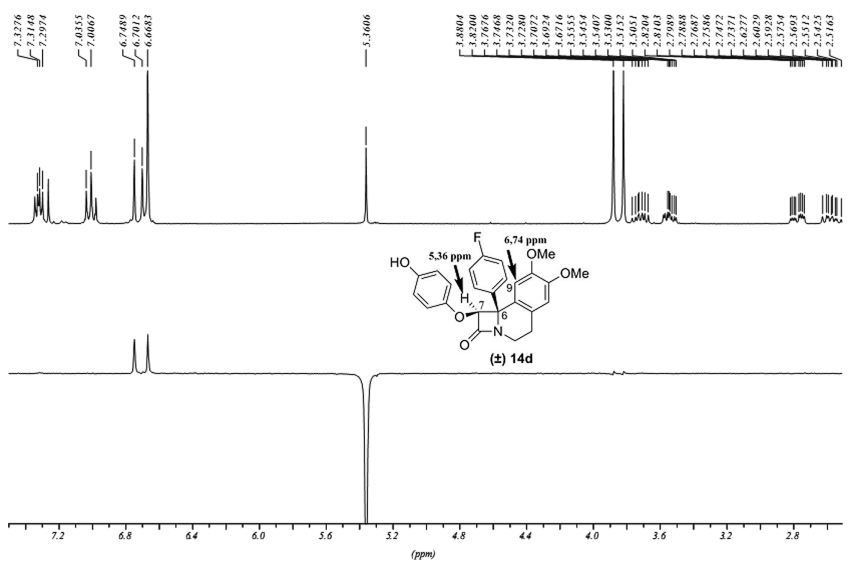

Figure 3

Staudinger reaction to the development of biologically promising compounds.

Acknowledgment. Financial support from Consejo Nacional de Investigaciones Científicas y Técnicas (CONICET), Agencia Nacional de Promoción Científica y Tecnológica, Fundación Prats and Universidad Nacional de Rosario from Argentina is gratefully acknowledged. L.M. thanks CONICET for fellowships.

Supporting Information Available. General information, compound characterization data, and ${ }^{1} \mathrm{H}$ NMR and ${ }^{13} \mathrm{C}$ NMR spectra of new compounds. This material is available free of change via the Internet at http://pubs.acs.org.

\section{References and Notes}

(1) Ren, X.-F.; Konaklieva, M. I.; Shi, H.; Dickey, S.; Lim, D. V.; Gonzalez, J.; Turos, E. J. Org. Chem. 1998, 63, 88988917.

(2) Dürckheimer, W.; Blumbach, J.; Lattrell, R.; Scheunemann, K. H. Angew. Chem. 1985, 97, 183-205.

(3) (a) Adlington, R. M.; Baldwin, J. E.; Chen, B.; Cooper, S. L.; McCoull, W.; Pritchard, G. J.; Howe, T. J.; Becker, G. W.; Hermann, R. B.; McNulty, A. M.; Neubauer, B. L. Bioorg. Med. Chem. Lett. 1997, 7, 1689-1694. (b) Annunziata, R.; Benaglia, M.; Cinquini, M.; Cozzi, F.; Puglisi, A. Bioorg. Med. Chem. 2002, 10, 1813-1818.

(4) Annunziata, R.; Benaglia, M.; Cinquini, M.; Cozzi, F.; Maggioni, F.; Puglisi, A. J. Org. Chem. 2003, 68, 2952-2955.

(5) Borthwick, A. D.; Weingarten, G.; Haley, T. M.; Tomaszewski, M.; Wang, W.; Hu, Z.; Bedard, J.; Jih, H.; Yuen, L.; Mansour, T. S. Bioorg. Med. Chem. Lett. 1998, 8, 365-370.
(6) Cvetovich, R. J.; Chartran, M.; Hartner, F. W.; Roberge, C.; Amato, J. S.; Grabowski, E. J. J. Org. Chem. 1996, 61, 6575-6580.

(7) Burnett, D. A. Curr. Med. Chem 2004, 11, 1873-1887, and references therein.

(8) (a) Setti, E. L.; Davis, D.; Chung, T.; McCarter, J. Bioorg. Med. Chem. Lett. 2003, 13, 2051-2053. (b) Zhou, N. E.; Guo, D.; Thomas, G.; Reddy, A. V. N.; Kaleta, J.; Purisima, E.; Menard, R.; Micetich, R. G.; Singh, R. Bioorg.z Med. Chem. Lett. 2003, 13, 139-141.

(9) Feledziak., M.; Michaux, C.; Urbach, A.; Labar, G.; Muccioli, G. G.; Lambert, D. M.; Marchand-Brynaert, J. J. Med. Chem. 2009, 52, 7054-7068.

(10) Rothstein, J. D.; Patel, S.; Regan, M. R.; Haenggeli, C.; Huang, Y. H.; Bergles, D. E.; Jin, L.; Dykes-Hoberg, M.; Vidensky, S.; Chung, D. S.; Toan, S. V.; Bruijn, L. I.; Su, Z.-Z.; Gupta, P.; Fishe, P. B. Nature 2005, 433, 73-77.

(11) Overbye, K. M.; Barrett, J. F. Drug Discovery Today 2005, $10,45-52$.

(12) (a) Singh, G. S. Mini-Rev. Med. Chem. 2004, 4, 69-92. (b) Singh, G. S. Mini-Rev. Med. Chem. 2004, 4, 93-109. (c) Testero, S. A.; Fisher, J. F.; Mobashery, S. $\beta$-Lactam Antibiotics. In Burger's Medicinal Chemistry, Drug Discovery and Development, 7th ed.; Abraham, D. J., Rotella, D. P., Eds.; John Wiley \& Sons: New York, 2010; pp 257-402.

(13) (a) Biondi, S.; Piga, E.; Rossi, T.; Vigelli, G. Bioorg. Med. Chem. Lett. 1997, 7, 2061-2066. (b) Kanno, O.; Kawamoto, I. Tetrahedron 2000, 56, 5639-5648. (c) Gómez-Gallego, M.; Mancheño, M. J.; Sierra, M. A. Tetrahedron 2000, 56, 57435774. (d) Alcaide, B.; Almendros, P. Curr. Med. Chem. 2004, 11, 1921-1949. (e) Mohar, B.; Stephan, M.; Urleb, U. Tetrahedron 2010, 66, 4144-4149.

(14) Paukner, S.; Hesse, L.; Prezelj, A.; Solmajer, T.; Urleb, U. J. Antimicrob. Chemother. 2009, 53, 505-511.

(15) Afonso, A.; Rosenblum, S. B.; Puar, M. S.; McPhail, A. T. Tetrahedron Lett. 1998, 39, 7431-7434.

(16) Banik, B. K.; Banik, I.; Becker, F. F. Top. Heterocycl. Chem. 2010, 22, 349-373.

(17) (a) Mata, E. G. Tetrahedron Lett. 1997, 38, 6335-6338. (b) Delpiccolo, C. M. L.; Mata, E. G. Tetrahedron: Asymmetry 1999, 10, 3893-3897. (c) Delpiccolo, C. M. L.; Mata, E. G. Tetrahedron: Asymmetry 2002, 13, 905-910. (d) Delpiccolo, C. M. L.; Fraga, M. A.; Mata, E. G. J. Comb. Chem. 2003, 5, 208-210. (e) Delpiccolo, C. M. L.; Mata, E. G. Tetrahedron Lett. 2004, 45, 4085-4088. (f) Delpiccolo, C. M. L.; Méndez, L.; Fraga, M. A.; Mata, E. G. J. Comb. Chem. 2005, 7, 331344. (g) Méndez, L.; Delpiccolo, C. M. L.; Mata, E. G. Synlett 2005, 1563-1566. (h) Testero, S. A.; Mata, E. G. Org. Lett. 2006, 8, 4783-4786. (i) Boggián, D. B.; Mata, E. G. Synthesis 2006, 3397-3404. (j) Poeylaut-Palena, A. A.; Mata, E. G. J. Comb. Chem. 2009, 11, 791-794.

(18) Méndez, L.; Testero, S. A.; Mata, E. G. J. Comb. Chem. 2007, 9, 189-192.

(19) Giralt, E.; Rizo, J.; Pedroso, E. Tetrahedron 1984, 40, 41414152.

(20) Georg, G. I.; Ravikumar, V. T. In The Organic Chemistry of $\beta$-Lactams; Georg, G. I., Ed.; Verlag Chemie: New York, 1993; pp 295-368.

(21) (a) Fülöp, F.; Bernáth, G. Curr. Org. Chem. 1999, 3, 1-24. (b) Csomós, P.; Martinek, T. A.; Lázár, L.; Fülöp, F. ARKIVOC 2003, v, 87-93.

(22) Zhao, B.; Yu, Y.; Eguchi, S. Org. Prep. Proc. Int. 1997, 29, 185-194.

(23) Typical procedure for the solid-phase synthesis of multicyclic $\beta$-lactam derivatives: The immobilized 4-hydroxyphenoxyacetic acid (5) (183.6 mg, $0.17 \mathrm{mmol})$ was suspended in anhydrous chloroform ( $2 \mathrm{~mL}$ ), and a solution of 6,7-dimethoxy1-phenyl-3,4-dihydroisoquinoline 12b $(227.22 \mathrm{mg}, 0.85 \mathrm{mmol}$, 5 equiv) in chloroform and triethylamine $(0.14 \mathrm{~mL}, 1.02$ mmol, 6 equiv) were added under a nitrogen atmosphere. After few minutes, Mukaiyama's reagent (8) (130.3 mg, $0.51 \mathrm{mmol}$, 3 equiv) was added, and the suspension was refluxed for $2 \mathrm{~h}$. 
Then, the reaction mixture was filtered, and the resin was washed successively with $\mathrm{CH}_{2} \mathrm{Cl}_{2}(3 \times 5 \mathrm{~mL})$, EtOAc $(3 \times$ $5 \mathrm{~mL}), \mathrm{MeOH}(3 \times 5 \mathrm{~mL})$, and $\mathrm{CH}_{2} \mathrm{Cl}_{2}(1 \times 5 \mathrm{~mL})$. After it was dried in vacuo, the resin was exposed to the same reaction conditions. Resin-bound $\beta$-lactam $\mathbf{1 3 b}$ was stirred in $3 \mathrm{~mL}$ of $10 \%$ TFA solution in $\mathrm{CH}_{2} \mathrm{Cl}_{2}$ for $1 \mathrm{~h}$. The mixture was filtered, the resin washed with $\mathrm{CH}_{2} \mathrm{Cl}_{2}$, and the filtrate concentrated at reduced pressure. This crude material was purified by silica gel column chromatography (hexane/EtOAc, 60:40) to provide $44.1 \mathrm{mg}$ of carbacepham derivative $14 \mathrm{~b}$ ( $77 \%$ overall yield based on initial loading level of the Wang resin).

(24) Beebe, X.; Schore, N. E.; Kurth, M. J. J. Org. Chem. 1995, 60, 4196-4203.
(25) (a) Furman, B.; Thürmer, R.; Kaluza, Z.; Lysek, R.; Voelter, W.; Chmielewski, M. Angew. Chem., Int. Ed. 1999, 38, 11211123. (b) Lei, M.; Cheng, M. A.; Wang, Y. G. Chin. Chem. Lett. 2003, 14, 6-8. (c) Gedey, S.; Van der Eycken, J.; Fülöp, F. Lett. Org. Chem. 2004, 1, 215-220.

(26) For reviews on solid-phase synthesis of $\beta$-lactams, see: (a) Mata, E. G. Curr. Pharm. Des. 1999, 5, 955-964. (b) Laborde, M. A.; Mata, E. G. Mini-Rev. Med. Chem. 2006, 6, 107-120. (c) Mandal, B.; Ghosh, P.; Basu, B. Top. Heterocycl. Chem. 2010, 22, 261-311.

CC100140R 